\title{
Mutants of Escherichia coli with Altered Surface Properties which are Refractory to Colicin E2, Sensitive to Ultraviolet Light and which can also Show Recombination Deficiency, Abortive Growth of Bacteriophage $\lambda$ and Filament Formation
}

\author{
By I. B. HOLLAND, E. J. THRELFALL, ÉVA M. HOLLAND, \\ VALERIE DARBY AND A. C. R. SAMSON \\ Department of Genetics, University of Leicester, Leicester, $L_{E I} 7 R H$
}

(Accepted for publication 28 May 1970)

\begin{abstract}
SUMMAR Y
Mutants refractory to colicin E2, previous phenotypic symbol RefII, have now been divided into two major phenotypic groups. CetC mutants in distinction to CetB mutants show increased sensitivity to u.v. and to a detergent (DOC). CetC mutants may also show other properties, including abortive growth of bacteriophage $\lambda$ and defective division. CetB mutants are refractory to $\mathrm{E}_{2}$ at $30^{\circ}$ but largely sensitive at $37^{\circ}$. CetC mutants are also refractory at $30^{\circ}$ but may be either sensitive or completely refractory at $37^{\circ}$. In contrast to $\mathrm{Rec}^{-}$mutants, CetC strains are not sensitive to gamma rays but two mutants show enhanced DNA breakdown after u.v. irradiation. CetC mutants seem defective in a specific membrane component which renders them insensitive to $\mathrm{E} 2$ and alteration of which can affect several aspects of DNA metabolism.
\end{abstract}

\section{INTRODUCTION}

One approach to the study of the functional organization of the bacterial membrane appears to be through the use of certain protein antibiotics, colicins. The general properties of colicins (see Review, Nomura, 1967) suggest that their primary site of action is the cytoplasmic membrane although they do not appear to induce detectable permeability changes in sensitive cells (Nomura, 1964). It is assumed, therefore, that colicins induce subtle changes in the physical properties of the cell membrane, which in turn induce the intracellular changes specific to each colicin. To establish the nature and normal functional role of colicin-specific sites in the cell surface, efforts have therefore been made to isolate mutants, resistant to colicin, with altered membranes. The isolation of mutants possibly of this type, which still adsorb colicin normally but remain refractory to its effect, has been described previously (Hill \& Holland, I967). The mutants included a class which were specifically refractory to colicin E 2 at $30^{\circ}$ but largely sensitive at higher temperatures. Further studies confirmed that $\mathrm{E} 2$ refractivity in one mutant, ASH IOI, was temperature-dependent and that the mutant growing at $40^{\circ}$ immediately became resistant to E 2 after a shift of temperature to $30^{\circ}$ (Holland, 1968). At $30^{\circ}$ inhibition of cell division and induction of rapid degradation of DNA, characteristic effects of $\mathrm{E}_{2}$ on sensitive cells, were not observed in this mutant. Studies of other mutants refractory to $\mathrm{E}_{2}$ have shown that a small proportion were also 
u.v.-sensitive, although this property was not apparently temperature-dependent (Holland, I967).

In all previous communications E2-refractory strains were designated as Ref I I mutants. In accordance with the recommendations of Clark, Demerec, Adelberg \& Hartman (1966), E2-refractory mutants are now identified by the symbol Cet (Colicin E-two). For convenience, mutants of normal u.v. sensitivity are designated CetB, whilst u.v.-sensitive, E2-refractory mutants are designated CetC. In this paper additional CetC mutants are described and the basis of their u.v. sensitivity further examined. The temperature dependence of E2-refractivity in these mutants has been found to be more complex than that of CetB mutants and they have acquired, in addition to u.v. sensitivity, several other mutant characteristics including altered cell surface properties. The properties of these mutants suggest that colicin E2 may normally interact with a part of the cell membrane which is involved in the regulation of cell division and in some aspects of DNA metabolism.

\section{METHODS}

The general properties of strains used in this study are shown in Table I. Mutant strains ASH IOI, IIO, I I I, I I 2 (Holland, I967, I968) and ASH I02, II3 (Holland \& Threlfall, 1969) have been studied previously. Strains ASH II4, II5 and II6 are described for the first time. E2-refractory strains ASH IOI, III and ASH II4 were derived from parental strain ASH I (HfrBII, thi- met $t^{-} t h y^{-} l e u^{-} s^{\mathrm{r}} \lambda^{-}$) whilst ASH I02, I I2, II3, I I 5 and I I6 were derived from the parental strain ASH IO (F- thi ${ }^{-}$ $m e t^{-}$thy- $\left.l e u^{-} l a c^{-} s t r^{\mathrm{r}} \lambda^{+}\right)$. The E2-refractory strain ASH I Io was derived from $\mathrm{HfrH}$ $\left(t h i^{-}\right.$thy $\left.y^{-} l a c^{-} s t r^{r} \lambda^{-}\right)$. The isolation and initial characterization of the mutants has also been described previously (Holland \& Threlfall, 1969).

Table I. Summary of phenotypic properties of CetB and CetC mutants

\begin{tabular}{|c|c|c|c|c|c|c|c|c|c|c|}
\hline & & & & & & Respo & se to & & $\begin{array}{l}\text { Recom- } \\
\text { bination }\end{array}$ & $\begin{array}{l}\text { Filament } \\
\text { forma- }\end{array}$ \\
\hline & & Sex & $25^{\circ}$ & $37^{\circ}$ & u.v. & $\mathrm{X}$-ray & DOC & $\lambda$ & ficiency & $(+/-)$ \\
\hline Parent & $\begin{array}{l}\text { ASH I } \\
\text { ASH IO }\end{array}$ & $\begin{array}{l}\mathrm{Hfr} \\
\mathrm{F}^{-}\end{array}$ & $\begin{array}{l}S \\
S\end{array}$ & $\begin{array}{l}\mathbf{S} \\
\mathrm{S}\end{array}$ & $\begin{array}{l}\mathbf{R} \\
\mathbf{R}\end{array}$ & $\begin{array}{l}\mathbf{R} \\
\mathbf{R}\end{array}$ & $\begin{array}{l}\mathbf{R} \\
\mathbf{R}\end{array}$ & $\begin{array}{l}S \\
S\end{array}$ & $\begin{array}{l}l^{*} \\
+\end{array}$ & - \\
\hline CetC & 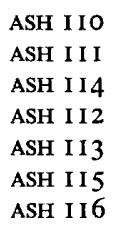 & $\begin{array}{l}\text { Hfr } \\
\text { Hfr } \\
\text { Hfr } \\
F^{-} \\
F^{-} \\
F^{-} \\
F^{-}\end{array}$ & $\begin{array}{l}\mathrm{R} \\
\mathrm{R} \\
\mathrm{R} \\
\mathrm{R} \\
\mathrm{R} \\
\mathrm{R} \\
\mathrm{R}\end{array}$ & $\begin{array}{l}\text { R } \\
\text { S } \\
R \\
R \\
S \\
S \\
S \\
S\end{array}$ & $\begin{array}{l}S \\
S \\
S \\
S \\
S \\
S \\
S\end{array}$ & $\begin{array}{l}l^{*} \\
\mathrm{R} \\
\mathrm{R} \\
\mathrm{R} \\
\mathrm{R} \\
\vdots \\
l\end{array}$ & $\begin{array}{l}S \\
S \\
S \\
S \\
S \\
S \\
S\end{array}$ & $\begin{array}{l}S \\
S \\
R \\
R \\
S \\
S \\
R\end{array}$ & $\begin{array}{c}1 \\
\operatorname{Rec}^{-} \\
\operatorname{Rec}^{-} \\
\operatorname{Rec}^{-} \\
\operatorname{Rec}^{-} \\
+ \\
+\end{array}$ & $\begin{array}{l}\mathrm{Fil}^{+} \\
\mathrm{Fi}^{+} \\
- \\
- \\
- \\
-\end{array}$ \\
\hline CetB & $\begin{array}{l}\text { ASH IOI } \\
\text { ASH IO2 }\end{array}$ & $\begin{array}{l}\text { Hfr } \\
\mathrm{F}^{-}\end{array}$ & $\begin{array}{l}\mathbf{R} \\
\mathbf{R}\end{array}$ & $\begin{array}{l}\mathrm{S} \\
\mathrm{S}\end{array}$ & $\begin{array}{l}\mathbf{R} \\
\mathbf{R}\end{array}$ & 1 & $\begin{array}{l}\mathbf{R} \\
\mathbf{R}\end{array}$ & $\begin{array}{l}S \\
S\end{array}$ & $\begin{array}{l}1 \\
+\end{array}$ & - \\
\hline
\end{tabular}

$\mathrm{R}$ denotes resistance, or refractivity; $\mathrm{S}$ denotes sensitivity. The response to colicin $\mathrm{E} 2$ was determined in liquid-grown cultures as in Fig. I. With phage $\lambda$, three strains, ASH 1 I 4, 112 and I 16 , showed increased but not complete resistance to the phage (see text); ${ }^{*}$ denotes strains not tested for this character.

The RecA strain KMBL 239 (rec 34) was obtained from Professor A. Rörsch, and the RecB mutant, JC 4457, was kindly provided by Dr A. J. Clark. Culture methods and production and assay of colicin E 2 (P9) obtained from Salmonella typhimurium LT 2906 were described previously (Hill \& Holland, 1967). 
Irradiation procedures. Ultraviolet irradiation. The source of u.v. was a low-pressure mercury lamp (Hanovia Ltd) used without filter and with an incident dose rate of $6.5 \mathrm{ergs} / \mathrm{mm}^{2}$. at $46 \mathrm{~cm}$. For quantitative determination of the u.v. sensitivity of mutant strains, the procedure described previously was used (Holland, 1967). Exponential cultures of various strains grown in tryptone broth (TB) were harvested, washed and resuspended in $0.07 \mathrm{M}$-phosphate buffer at $\mathrm{IO}^{6}$ bacteria $/ \mathrm{ml}$. Appropriate dilutions of bacteria were then plated on tryptone ( $1 \%$ Oxoid tryptone, $0.5 \% \mathrm{w} / \mathrm{v} \mathrm{NaCl}$ ) agar plates, irradiated and incubated in the dark for $\mathrm{I} 4 \mathrm{~h}$. at $37^{\circ}$ before counting.

Gamma irradiation. Exponential cultures $\left(5 \times 10^{8}\right.$ bacteria/ml. $)$ of mutants in $\mathrm{TB}$ media were harvested, washed and resuspended in $0.07 \mathrm{M}$-phosphate buffer at $10^{8}$ bacteria $/ \mathrm{ml}$; $2 \mathrm{ml}$. aliquots in $1 \frac{1}{4}$ in. $\times \frac{3}{8}$ in. glass vials were then irradiated in a Gammacell 200 (Atomic Energy of Canada, Ltd) output 0.13 megarads/h. Irradiated samples were diluted, plated on TB plates, and survival determined after $14 \mathrm{~h}$. at $37^{\circ}$.

Determination of u.v.-induced DNA breakdown. Exponentially growing cultures of strains in Difco nutrient broth (NB) were labelled with $\mathrm{H}^{3}$ thymine ( $16 \mu \mathrm{Ci} / \mu \mathrm{g}$. thymine $/ \mathrm{ml}$.) in the presence of $100 \mu \mathrm{g} . / \mathrm{ml}$. deoxyuridine, for five generations and harvested when the density reached $3 \times 10^{8}$ bacteria $/ \mathrm{ml}$. Labelled cells were washed twice and finally resuspended $\left(2 \times 10^{7}\right.$ bacteria $/ \mathrm{ml}$.) in $0.07 \mathrm{M}$-phosphate buffer $\mathrm{pH} 7.2$ plus $25 \mu \mathrm{g}$. $/ \mathrm{ml}$. cold thymine; $8 \mathrm{ml}$. samples were irradiated in a thin layer $(2 \mathrm{~mm}$.) and then diluted with an equal volume of NB and reincubated in dim light at $37^{\circ}$. Samples ( $0.5 \mathrm{ml}$.) were removed at intervals, mixed with $0.5 \mathrm{ml} .10 \%$ cold trichloroacetic acid and cold and hot acid soluble counts analysed as described by Howard-Flanders \& Theriot (1966). Full details of labelling procedures and methods of the determination of E2-induced DNA breakdown have been described previously (Holland, 1968).

Growth of bacteriophage $\lambda$. Production and assay of $\lambda$ and $\lambda g v$ (Jacob \& Wollman, 1953) have been described previously (Holland, 1967). One-step growth experiments were carried out by the standard technique based upon that described by Ellis \& Delbrück (I939) using Escherichia coli $\mathrm{c} 600$ as indicator. The medium used in onestep growth experiments consisted of an M9 basal medium (Anderson, 1946) with $\mathrm{I} \cdot 4 \%(\mathrm{w} / \mathrm{v})$ maltose as carbon source and supplemented with $\mathrm{I} \%(\mathrm{w} / \mathrm{v})$ Casamino acids (Difco), $40 \mu \mathrm{g} . / \mathrm{ml}$. thymine and $10 \mu \mathrm{g} / \mathrm{ml}$. vitamin B I. For the assay of intracellular phage, $0.5 \mathrm{ml}$. aliquots of infected cultures were removed, mixed with an equal volume of $10 \%(\mathrm{v} / \mathrm{v})$ chloroform in phage buffer $\left(0.02 \mathrm{M}\right.$-tris $\mathrm{pH} 7 \cdot 2,0.01 \mathrm{M}-\mathrm{MgSO}_{4}$, $0.005 \%$ gelatin) and blended vigorously on a Vortex mixer. Finally, the suspension was incubated $10 \mathrm{~min}$. at $37^{\circ}$ to complete lysis, and, after cooling, $0.1 \mathrm{ml}$. samples were assayed for free phage.

\section{RESULTS}

\section{Response of Cet mutants to colicin $E_{2}$}

In the initial characterization of E2-refractory mutants (Hill \& Holland, 1967), refractivity to colicin was determined in cross-streak tests on nutrient broth agar. The majority of the mutants, although pregrown at $37^{\circ}$, were refractory to $\mathrm{E} 2$ at $25^{\circ}$ but completely sensitive at $37^{\circ}$. In one mutant, ASH I I 2, some growth in the presence of E 2 was observed at $37^{\circ}$ and so sensitivity in this strain was not complete at high temperature. Similar results were again obtained in cross-streak tests with all the mutants examined in this study. When sensitivity to colicin was determined in liquid culture, although all strains grown and tested at $30^{\circ}$ were still refractory to $\mathrm{E} 2$, the response at $37^{\circ}$ varied 
widely in different mutants. As shown in Fig. I, some strains, including ASH I I2, were completely refractory to E2 whilst others, e.g. ASH I I I were quite sensitive. Strains ASH IOI and ASH I02, which appeared to be typical of the majority of Cet mutants, showed, as described previously (Holland, 1968), an intermediate sensitivity at $37^{\circ}$. The induction of DNA breakdown by colicin E 2 at $37^{\circ}$ was also examined in all the mutants. As found previously and as shown in Fig. 2, the extent of E2-induced DNA breakdown at $37^{\circ}$ closely parallels the E2-sensitivity of each strain at this temperature.

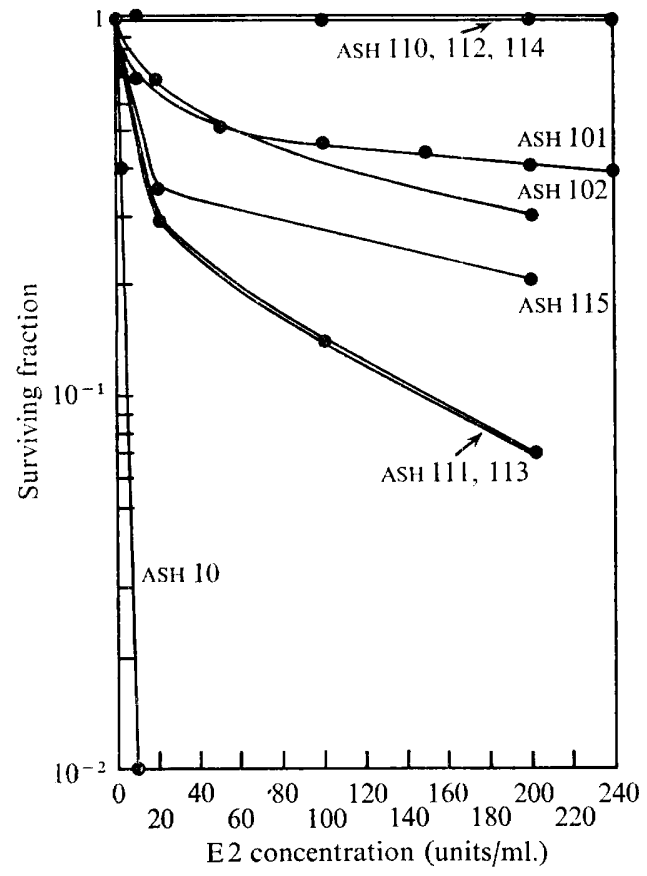

Fig. I

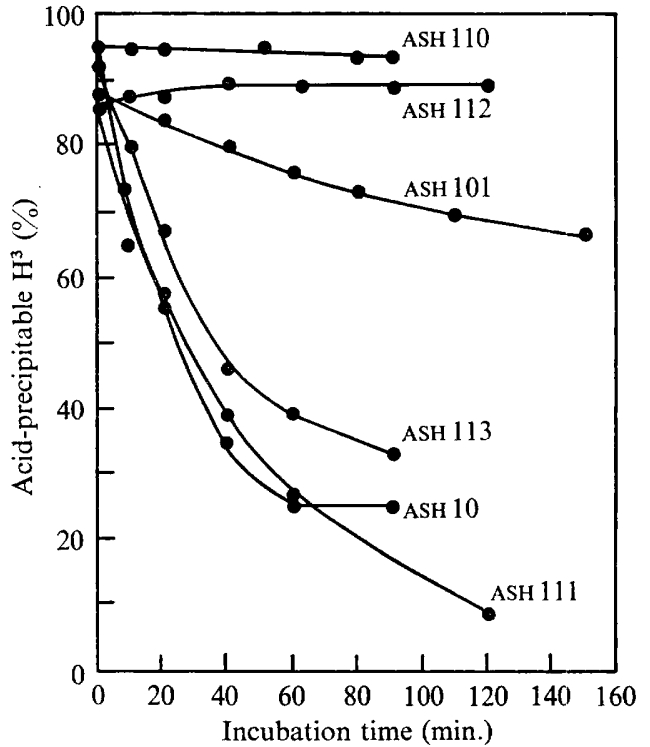

Fig. 2

Fig. I. Sensitivity of CetC mutants to colicin E 2 at $37^{\circ}$. Exponentially growing cultures in NB medium of various CetC mutants, two CetB mutants (ASH IOI and IO2) and a wild-type strain, ASH IO, were adjusted to $10^{8}$ bacteria $/ \mathrm{ml}$. After treatment with different concentrations of colicin $\mathrm{E}_{2}$ for $40 \mathrm{~min}$. at $37^{\circ}$, the surviving fractions were determined by plating on NB agar plates.

Fig. 2. Colicin-induced DNA breakdown in CetC mutants at $37^{\circ}$. Bacteria were labelled by growth in NB media plus $\mathrm{H}^{3}$ thymine as described in Methods, harvested, washed and resuspended in NB at $2 \times 10^{7}$ bacteria/ml. E 2 was added and the cells reincubated with shaking at $37^{\circ}$. Samples ( $1.0 \mathrm{ml}$.) were removed at intervals, mixed with $4 \mathrm{ml} .10 \%$ ice-cold TCA and the content of acid-soluble and acid-precipitable radioactivity determined as described previously (Holland, 1968). The colicin concentrations used were 1000 units $/ \mathrm{ml}$. for ASH I IO, II 2; 400 units $/ \mathrm{ml}$. for ASH IOI, III and I I ; IOO units $/ \mathrm{ml}$. for ASH IO.

Ultraviolet-sensitive Cet mutants. When further properties of Cet mutants were examined they were found to be divisible into two major groups. CetB mutants, e.g. ASH IOI and ASH 102, apparently differ from the wild-type only in their refractivity to colicin E2. CetC mutants, e.g. ASH I I2, in contrast have acquired a varied range of additional properties (Table I). However, CetC mutants, which contribute about $15 \%$ 
of all Cet mutants, i.e. seven out of about 50 tested, have one property in common: they are all u.v.-sensitive. The u.v. sensitivity of several CetC mutants at $37^{\circ}$ is shown in Fig. 3. The mutants again show a wide range of response with those mutants showing maximum refractivity to E2 at $37^{\circ}$ (ASH II 2 and ASH II4) being the least sensitive to u.v. The u.v.-sensitivity of ASH II I varied somewhat in different experiments (see also Holland, 1967) but was usually similar to that shown in Fig. 3.

It was previously reported (Holland, I967) that CetC mutants ASH I IO and ASH II 3 , like $\mathrm{Rec}^{-}$mutants, are still capable of host-cell reactivation (i.e. they are $\mathrm{Hcr}^{+}$). However, unlike $\mathrm{Rec}^{-}$mutants, $\mathrm{CetC}$ mutants are not particularly sensitive to gammairradiation (Fig. 4).

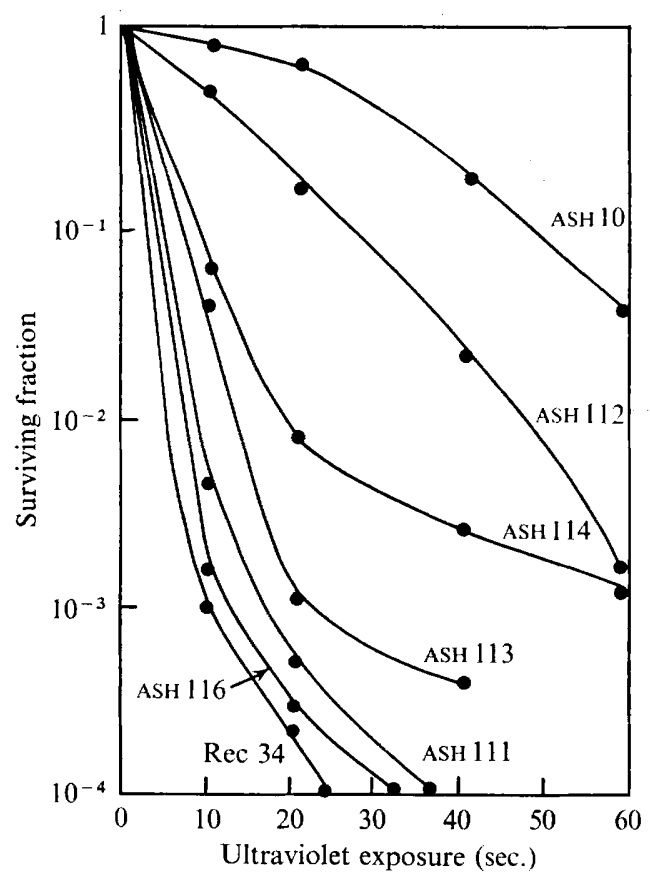

Fig. 3

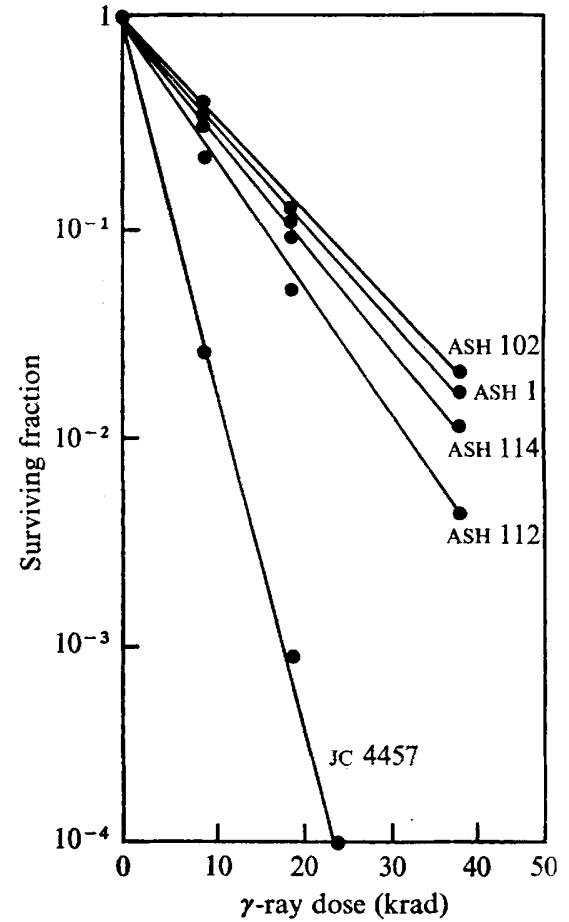

Fig. 4

Fig. 3. Ultraviolet sensitivity of CetC mutants at $37^{\circ}$. The cet ${ }^{+}$strain ASH Io and the recA mutant rec 34 were included as controls.

Fig. 4. Gamma-ray sensitivity of Cet mutants. The rec B mutant, Jc 4457, an X-ray sensitive strain, was included as a control.

Ultraviolet-induced DNA breakdown in CetC mutants. Howard-Flanders \& Theriot (I966) and Willetts \& Clark (1969) have shown that whilst at least some RecB and RecC mutants show a 'cautious' (less than wild-type) DNA breakdown, RecA mutants show 'reckless' DNA breakdown after u.v. irradiation. The CetC mutant ASH I I I was previously found to show enhanced DNA breakdown after u.v. irradiation (Holland, 1967) and several other CetC mutants have now been tested for this property. The u.v.-induced DNA breakdown patterns obtained (Fig. 5) demonstrate that none of the mutants fall clearly into the two categories originally defined by Howard-Flanders \& Theriot (1966). Although ASH I I 4 and ASH I I I and possibly ASH I I 3 showed increased 
breakdown over the parental type after large doses of u.v., they could still be distinguished from typical RecA mutants which characteristically show extensive spontaneous DNA breakdown, have large intracellular nucleotide pools and rapidly degrade their DNA after small doses (50 ergs) of u.v. (Howard-Flanders \& Theriot, I966). With other CetC mutants DNA breakdown after irradiation was similar to the parental strain ASH IO or the CetB mutant ASH Ior.

Detergent sensitivity of CetC mutants. De Zwaig and Luria (I967) reported that some mutants refractory to both colicins $\mathrm{E}_{2}$ and $\mathrm{E}_{3}$ showed increased sensitivity, under certain cultural conditions, to sodium deoxycholate (DOC) and to EDTA. They

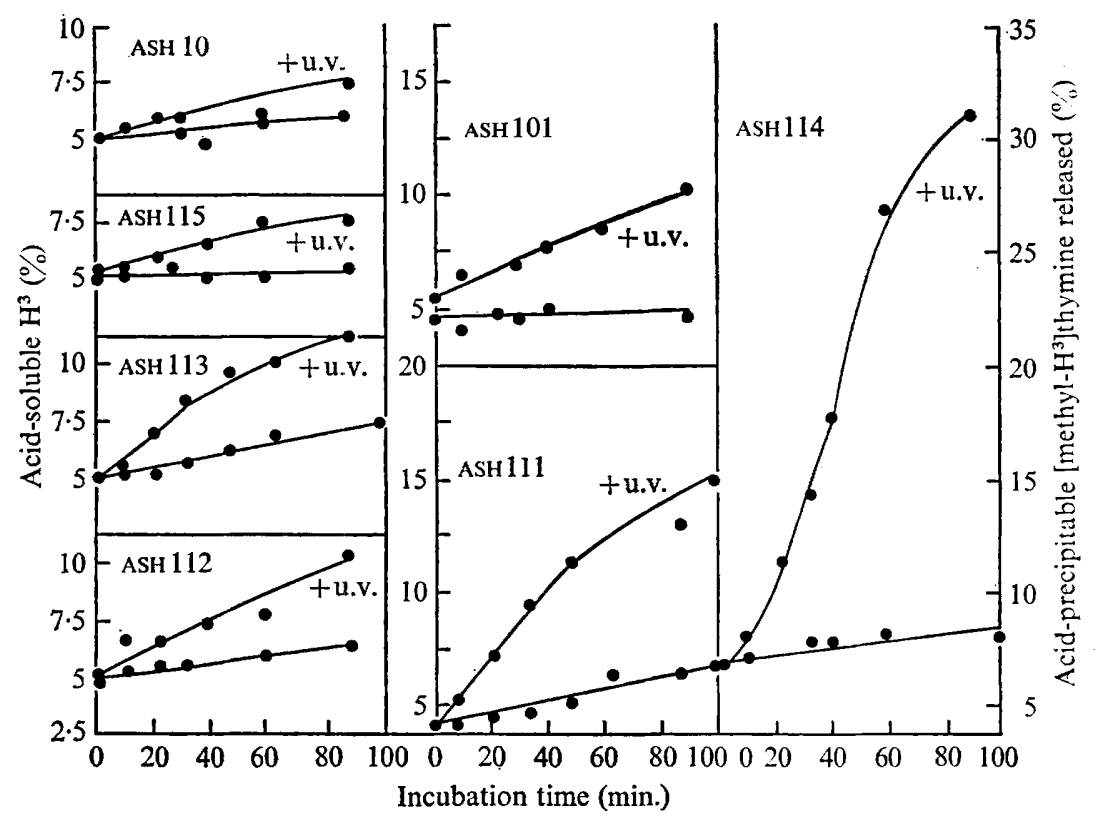

Fig. 5. DNA breakdown in CetC mutants after $400 \mathrm{ergs} / \mathrm{mm} .^{2}$ u.v. Content of acid-soluble $\mathrm{H}^{3}$ thymine as a percentage of total radioactivity of the culture is plotted against time. The control culture, ASH $10\left(\mathrm{cet}^{+}\right)$, is isogenic with the CetC mutants ASH I 12, I I 3 and I I 5 whilst the CetB mutant ASH IOI is shown as an isogenic control for CetC mutants ASH II I and ASH I I 4.

suggested that this and other properties of the mutants indicated that refractivity to colicin was associated with a change in properties of some component of the cytoplasmic membrane. When grown in nutrient broth, all CetC mutants showed greatly increased sensitivity to DOC whilst CetB mutants were largely unaffected (Fig. 6). For these tests the bacteria were first grown at $37^{\circ}$ and then tested for DOC-sensitivity at either $25^{\circ}$ or $37^{\circ}$. The CetC strains were almost equally sensitive at both temperatures as with their response to u.v. As in other tests the mutants showed a wide range of response to the treatment with, to some extent, the mutants most sensitive to u.v. being least sensitive to the detergent. Some CetB mutants also showed slight sensitivity to DOC (e.g. ASH I02) but the effect was much less than that observed with CetC strains.

Other u.v.-sensitive mutants of Escherichia coli $\mathrm{K}$ I2 including RecA, RecB and $\mathrm{Uvr}^{-}$strains and an $\mathrm{Hsp}^{-}$(host specificity) mutant were also tested for DOC sensi- 
tivity and found to be resistant. Increased DOC-sensitivity therefore appears to be a specific change associated with the CetC phenotype.

\section{Effect of temperature shift on E2-induced DNA breakdown in CetC mutant ASH II 3}

Mutants refractory to colicin E2 should conceivably arise through a change in the activity of the nuclease normally activated by the presence of the colicin. Furthermore, since particular strains, e.g. ASH I I I and ASH II3, are very sensitive to E 2 at high temperature but refractory at low temperature, it was of interest to determine whether such mutants produced a cold-sensitive nuclease. A culture of ASH II 3 was first pre-

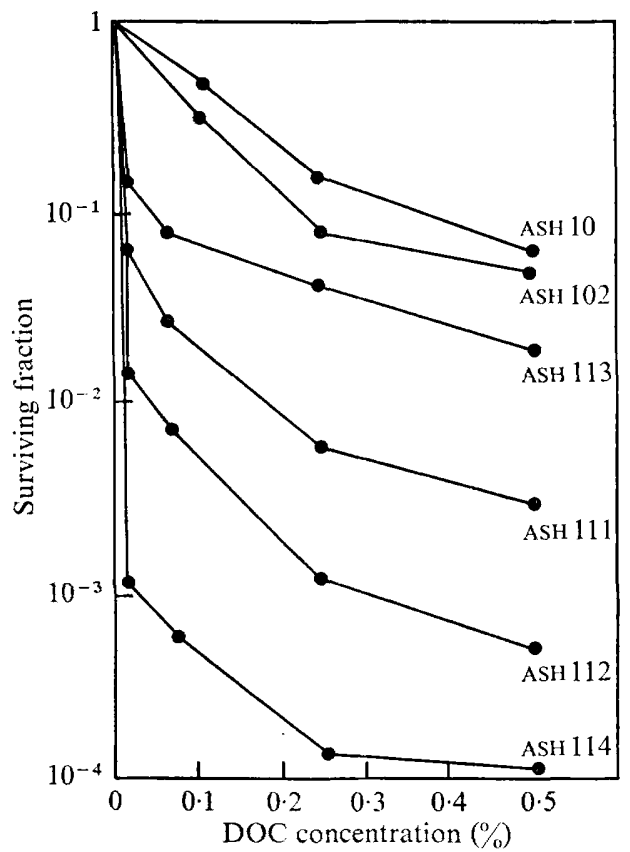

Fig. 6. Sensitivity of CetC mutants to sodium deoxycholate (DOC). Strains were grown to $5 \times 10^{8}$ bacteria $/ \mathrm{ml}$. in NB medium at $37^{\circ}$. The bacteria were then plated, after appropriate dilution, onto NB agar plates containing various concentrations of the detergent. Plates were incubated at $25^{\circ}$ for $24 \mathrm{~h}$. and the fraction surviving at each DOC concentration calculated. Similar results were obtained when plates were incubated at $37^{\circ}$.

labelled with $\mathrm{H}^{3}$ thymine at $37^{\circ}$ and colicin $\mathrm{E}_{2}$ was added to several different samples. At various times treated cultures were shifted to $30^{\circ}$ and the effect on DNA breakdown determined at intervals. As shown in Fig. $7 b$, temperature shift, even at time zero, did not prevent E2-induced DNA breakdown. The observed reduction in the rate of breakdown is compatible with the reduced activity of a normal enyzme operating at $30^{\circ}$ rather than at $37^{\circ}$ and in no way indicates instability of a nuclease at low temperature. Moreover, cultures shifted to $30^{\circ}$ for at least $20 \mathrm{~min}$. before addition of $\mathrm{E}_{2}$ still showed considerable DNA breakdown upon subsequent addition of E2 (Fig. 7a). Similar results were obtained with the CetC mutant ASH I I I. Neither of these strains therefore produce an E2-specific nuclease which is unstable at low temperature. The results do not, however, exclude the possibility that the mutants produce an altered 
nuclease in the form of an aggregate, functioning at both $37^{\circ}$ and $30^{\circ}$, which can be assembled at $37^{\circ}$ but not at $30^{\circ}$.

The results shown in Fig. $7 a$ also indicate a further possible difference between CetB and CetC mutants. Previous studies with CetB mutant ASH Ior (Holland, 1968) showed that this strain produced an altered cellular constituent which, after temperature shift from high to low temperature, immediately underwent a change which rendered the cells insensitive to the bacteriocidal effects of E2. In the present study the

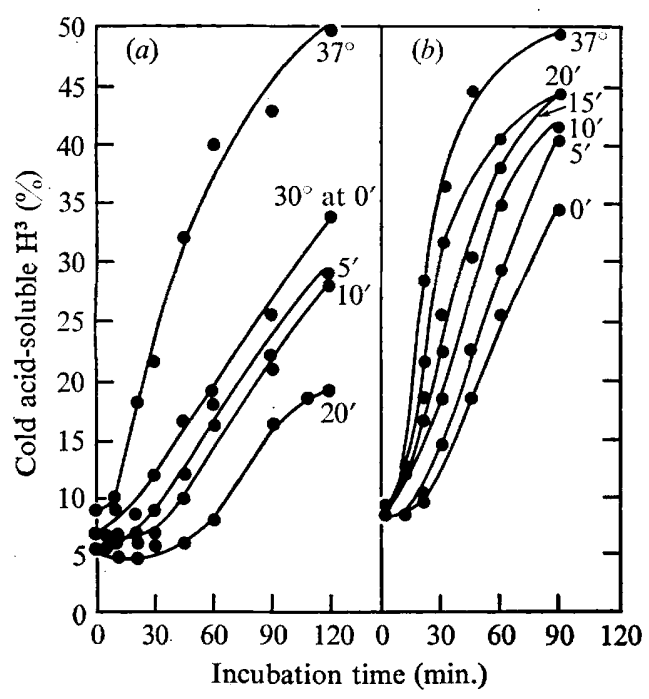

Fig. 7

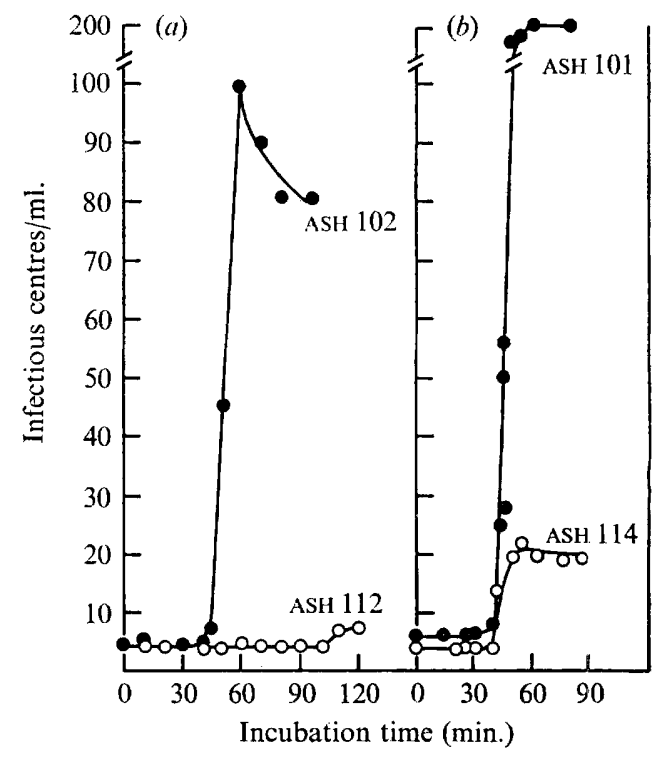

Fig. 8

Fig. 7. Effect of temperature shift on E 2-induced DNA breakdown in CetC mutant ASH 113. Strain ASH I I 3 was labelled with $\mathrm{H}^{3}$ thymine during growth at $37^{\circ}$ as described in Fig. 2 and Methods. The labelled bacteria were washed, resuspended at $2 \times 10^{7}$ bacteria $/ \mathrm{ml}$. in NB medium and kept at $37^{\circ}$ for $10 \mathrm{~min}$. before use.

(a) At time zero E 2 (50 units $/ \mathrm{ml}$ ) was added to each of two cultures, one was incubated at $37^{\circ}$ and the other immediately shifted to $30^{\circ}$. E 2 was also added to other cultures after 5 , Io and $20 \mathrm{~min}$. incubation at $30^{\circ}$ respectively. Release of $\mathrm{H}^{3}$ thymine as cold acid-soluble material was determined, as for Fig. 2, following temperature shift and the addition of colicin. In a control culture (not shown) growing at $30^{\circ}$ throughout, addition of colicin $\mathrm{E} 2$ produced no increase in the release of soluble $\mathrm{H}^{3}$ thymine over a $2 \mathrm{~h}$. period.

(b) Colicin E 2 (50 units $/ \mathrm{ml}$.) was added to several cultures of ASH I I 3 and one culture shifted to $30^{\circ}$ at each of the times indicated by the curves. One culture was maintained at $37^{\circ}$ throughout.

Fig. 8. Abortive growth of bacteriophage $\lambda$ in some CetC mutants. The number of infectious centres obtained in one-step growth experiments is plotted against time for each phagebacterial system. (a) Growth of $\lambda g v$ on the lysogenic strains ASH 102 (CetB) and ASH 112 (CetC). (b) Growth of $\lambda$ on non-lysogenic strains ASH IOI (CetB) and ASH I I4 (CetC).

bacteriocidal effects of $\mathrm{E}_{2}$ under conditions of temperature shift were not measured. Nevertheless, the results shown in Fig. $7 a$ indicate that in this CetC mutant extensive growth at low temperature is required before E2-refractivity is expressed. The coldsensitive lesion leading to $\mathrm{E}_{2}$ refractivity in CetB mutants and in at least some CetC mutants may therefore be different. 
Increased resistance to bacteriophage $\lambda$ amongst CetC mutants. Since the replication of $\lambda$ and $\varnothing \mathrm{XI} 74$ DNA has been reported to take place at specific membrane sites (Knippers \& Sinsheimer, I968; Salivar \& Sinsheimer, 1969), the sensitivity of various Cet mutants to phage $\lambda$ was also determined. So far, out of 30 strains tested, three CetC mutants (Table I) displayed increased resistance of some kind of $\lambda$ or its virulent derivative $\lambda g v$. This was reflected in the formation of minute plaques and reduced plating efficiencies. All three strains (ASH I I2, I I 4 and II6) nevertheless appeared to adsorb $\lambda$ with an efficiency equal to that of wild-type $c e t^{+}$strains. When one-step growth experiments were carried out with ASH I I 2 and ASH I I 4 , infectious centres were formed at normal frequencies indicating that both adsorption and injection of $\lambda$ DNA were normal under these conditions. As shown in Fig. $8 b$, however, the average burst-size for $\lambda$ or $\lambda g v$ in ASH I I 4 was only 5. This compares with burst sizes of 30 to 35 in the CetB mutant ASH IOI or in $\mathrm{Cet}^{+}$parental strains. Growth of $\lambda g v$ in ASH II 2 was found to be even more restricted with a maximum burst size of $\mathrm{I}$ to 2 phage particles per bacterium compared to 25 to 30 in the CetB control ASH 102. Liberation of mature phage was also greatly delayed in the ASH II 2 host, but the low burst was not apparently due to lysis inhibition since premature disruption of infected cells with chloroform did not increase the yield. The reason for the restriction of $\lambda$ multiplication in these CetC mutants is as yet unknown, but further experiments will be carried out to determine which particular step in the growth cycle is blocked.

Other properties of CetC mutants. At least two out of the seven CetC mutants so far studied show a further mutant phenotype, filament formation. These strains, ASH I Io and ASH II I, which both plate $\lambda$ normally, produce, especially on solid nutrient agar media, large numbers of filaments up to $30 \mu \mathrm{m}$. in length, unlike all the other CetC mutants so far studied. With one exception (ASH I I 6) CetC mutants do not form mucoid colonies on minimal or nutrient agar. In these respects they are clearly distinct from u.v.-sensitive mutants of the Lon-type (Howard-Flanders, Simson \& Theriot, I964) in which u.v. sensitivity has been attributed to defective control of cellular polysaccharide synthesis (Walker \& Pardee, 1967). CetC mutants may be further distinguished from Lon-type mutants by their recombination deficiency which is described in the accompanying paper (Threlfall \& Holland, 1970).

Table I summarizes the main properties of CetC mutants described so far, but a further important characteristic of the mutants should be noted. CetC strains, in contrast to CetB mutants, grow more slowly than wild-type strains in both nutrient and minimal media, and in some cases give reduced ( 40 to $50 \%$ ) colony counts when plated on agar. These characteristics are probably a reflexion of surface defects which may be clearly seen by phase contrast microscopy, particularly with stationary phase cultures. Many free spheroplasts, organisms showing extrusion of almost free spheroplasts and even branched organisms are present. These characteristics have not been observed in CetB, Uvr ${ }^{-}, \operatorname{Rec} A, \operatorname{RecB}$ and $\operatorname{RecC}$ mutants examined by us.

\section{DISCUSSION}

Adsorption of colicin E2 is normally followed by rapid degradation of DNA and the inhibition of division. Cet mutants, refractory to $\mathrm{E} 2$, have now been isolated from several Escherichia coli $\mathrm{K}$ I 2 strains. These strains still adsorb E 2 but remain completely refractory to its effect at $30^{\circ}$ although the majority are largely sensitive at $37^{\circ}$. All Cet 
mutants so far studied show normal sensitivity to colicin $\mathrm{E}_{\mathrm{I}}$, bacteriophage BF 23 and to colicin E3, a colicin which appears to utilize the same initial receptor as E2 (Maeda \& Nomura, I966; Hill \& Holland, 1967). The mutants also appear unchanged in their sensitivity to colicin $\mathrm{K}$ and to bacteriophage $\mathrm{T}_{\mathrm{I}}$ (Naysmith, 1967). Colicin E2 refractivity appears therefore to be associated with a highly specific surface or intracellular change rendering interaction with this colicin ineffective.

Mutants refractory to $\mathrm{E} 2$ can be divided into two phenotypic groups: those, CetB, which have acquired E2-refractivity only, and those, CetC, which are also u.v.- and DOC-sensitive. Most CetC mutants also appear to be recombination-deficient in some way (Holland \& Threlfall, 1969; Threlfall \& Holland, 1970). In addition, two CetC mutants show filament formation under normal growth conditions whilst three other mutants support only poor growth of bacteriophage $\lambda$. Despite these wide variations in phenotype, genetic studies have shown that $\operatorname{cet} \mathrm{B}$ and $\operatorname{cet} \mathrm{C}$ loci are very closely linked. Furthermore, all the additional characteristics associated with $\mathrm{Cet} C$ refractivity appear to be the pleiotropic effects of a single gene closely linked to, if not identical with, the cet $\mathrm{C}$ locus, and not the result of several independent mutations (Threlfall \& Holland, 1970). Despite the close linkage of $\operatorname{cet} \mathrm{B}$ and $\operatorname{cet} \mathrm{C}$ loci, the radical differences in the properties of these mutants indicate that at least two distinct cistrons may be involved, and complementation studies are being carried out to test this.

Since colicins appear to exert their effects at the level of the cytoplasmic membrane, some mutants refractory to their action might be expected to have altered membranes. Both the increased detergent sensitivity of the CetC mutants and the microscopic evidence of surface abnormality strongly suggest that the mutants do have altered surfaces. Moreover, preliminary experiments have shown that membrane preparations from strains ASH II I and ASH I I 4 also have altered protein patterns on acrylamide gels when compared to wild-types (Samson \& Holland, unpublished results).

The complex pleiotropy of CetC mutants may be best explained on the basis of either of the following two models. The first model assumes that the cet $^{+}$gene constitutes part of an operon concerned with DNA metabolism and cell surface formation. Mutations in this gene might then arise having strong polar or pseudopolar effects upon adjacent genes (cf. Fink, I966; Giles, Case, Partridge \& Ahmed, I967; Zipser, 1969). The second model supposes that the cet $^{+}$gene determines the synthesis of a component of the cell membrane, malformation of which can directly or indirectly affect u.v. sensitivity, recombinant formation, cell division and, in some cases, growth of $\lambda$. Different mutations in the cet $\mathrm{C}$ gene would then give rise to the pleiotropic effects observed. Further genetic analysis of CetC mutants is now being carried out to test the validity of the first model. To test the second model, a qualitative study of the proteins present in membrane preparations from CetB and CetC mutants and their revertants is in progress. Further investigation of the molecular basis of the u.v. sensitivity of CetC mutants may also aid the understanding of CetC pleiotropy. Results obtained so far indicate that the u.v. sensitivity of these mutants differs from that of all Uvr, Rec and Lon mutants so far described. It is still not clear, however, whether CetC mutants are defective in repair of DNA or in some aspect of cell division which prevents normal recovery from u.v.irradiation.

The mode of action of colicin $\mathrm{E}_{2}$ and the properties of Cet mutants indicate that E2 normally interacts with a unique membrane site. This could be the part of the membrane which binds the DNA and which has been implicated in the cell division 
process (Jacob, Brenner \& Cuzin, I963; Ryter, I968). Comparison of the properties of this membrane fraction which can perhaps be isolated with its attendant DNA (see Tremblay, Daniels \& Schaechter, I969), with those of the remainder of the cell membrane in wild-type and in Cet mutants, should provide a crucial test of our hypothesis.

Part of this work was supported by a grant (G. 967/194/B) from the Medical Research Council. E.J.T. and A.C.R.S. gratefully acknowledge receipt of a Science Research Council Studentship.

\section{REFERENCES}

ANDERson, H. (1946). Growth requirements of virus resistant mutants of a bacterial strain. Proceedings of the National Academy of Sciences of the United States of America 32, I 20-128.

Clark, A. J., Demerec, M., Adelberg, E. A. \& Hartman, P. E. (1966). A proposal for uniform nomenclature in bacterial genetics. Genetics, Princeton 54, 6I-76.

DE ZWAIG, R. N. \& LURIA, S. E. (1967). Genetics and physiology of colicin tolerant mutants of $E$. coli. Journal of Bacteriology 94, I I I 2-1 123.

Ellis, E. L. \& DeLbrüCK, M. (1939). The growth of bacteriophage. Journal of General Physiology 22, 365-384.

FINK, G. R. (1966). A cluster of genes controlling three enzymes in histidine biosynthesis in Saccharomyces cerevisiae. Genetics, Princeton 53, 445-459.

Giles, N. H., Case, M. E., Partridge, C. W. H. \& Ahmed, S. I. (1967). A gene cluster in Neurospora crassa coding for an aggregate of five aromatic synthetic enzymes. Proceedings of the National Academy of Sciences of the United States of America 58, 1453-1460.

Hill, C. \& Holland, I. B. (1967). Genetic basis of colicin E sensitivity in Escherichia coli. I. Isolation and properties of refractory mutants and the preliminary mapping of their mutations. Journal of Bacteriology 94, 677-686.

Holland, I. B. (1967). The properties of u.v.-sensitive mutants of Escherichia coli $\mathrm{K} \mathrm{I} 2$ which are also refractory to colicin E2. Molecular and General Genetics 100, 242-25I.

Holland, I. B. (1968). Properties of Escherichia coli $\mathrm{K}$ I 2 mutants which show conditional refractivity to colicin E2. Journal of Molecular Biology 31, 267-275.

Holland, I. B. \& Threlfall, E. J. (1969). Identification of closely linked loci controlling ultraviolet sensitivity and refractivity to colicin E2 in Escherichia coli. Journal of Bacteriology 97, 9I-96.

Howard-Flanders, P., Simson, E. \& Theriot, L. (I964). A locus that controls filament formation and sensitivity to radiation in E. coli $\mathrm{K}$ I2. Genetics, Princeton 49, 237-246.

Howard-Flanders, P. \& Theriot, L. (I966). Mutants of E. coli $\mathrm{K} I 2$ defective in DNA repair and genetic recombination. Genetics, Princeton 53, I I $37-1$ I 50.

JACOB, F. \& Wollman, E. (1953). Induction of phage development in lysogenic bacteria. Cold Spring Harbor Symposia on Quantitative Biology 18, IOI-I I2.

JACOB, F., BRENNER, S. \& CUZIN, F. (1963). On the regulation of DNA replication in bacteria. Cold Spring Harbor Symposia on Quantitative Biology 28, 329-348.

KNIPPERS, R. \& SinSHeimer, R. L. (1968). Process of infection with bacteriophage ØXI74. XX. Attachment of parental DNA of bacteriophage $\emptyset \times 174$ to a fast sedimenting cell component. Journal of Molecular Biology 34, 17-29.

Maeda, A. \& Nomura, M. (I966). Interaction of colicins with bacterial cells. I. Studies with radioactive colicins. Journal of Bacteriology 9r, 685-694.

NAYSMITH, C. (NÉE HILL) (1967). Characterization and genetic analysis of colicin E-resistant mutants of Escherichia coli $\mathrm{K} 12$. M.Sc. Thesis, University of Leicester.

Nomura, M. (1964). Mechanism of action of colicines. Proceedings of the National Academy of Sciences of the United States of America 52, 1514-1521.

Nomura, M. (1967). Colicins and related bacteriocins. Annual Review of Microbiology 21, 257-284.

RYTER, A. (1968). Association of the nucleus and the membrane of bacteria. A morphological study. Bacteriological Reviews 32, 39-54.

SALIVAR, W. O. \& SiNSHEIMER, R. L. (I969). Intracellular location and number of replicating parental DNA molecules of bacteriophages $\lambda$ and ØXI 74. Journal of Molecular Biology 4I, 39-65. 
Threlfall, E. J. \& Holland, I. B. (1970). Co-transduction with $\operatorname{ser} B$ of a pleiotropic mutation affecting colicin $\mathrm{E} 2$ refractivity, ultraviolet sensitivity, recombination proficiency and surface properties of Escherichia coli K I2. Journal of General Microbiology 62, 383-398.

Tremblay, G. Y., Daniels, M. J. \& Schaechter, M. (1969). Isolation of a cell-membrane-DNAnascent RNA complex from bacteria. Journal of Molecular Biology 40, 65-76.

Walker, J. R. \& PARDEE, A. B. (1967). Conditional mutations involving septum formation in Escherichia coli. Journal of Bacteriology 93, 107-114.

WillETTS, N. S. \& CLARK, A. J. (1969). Characteristics of some multiple recombination deficient strains of Escherichia coli. Journal of Bacteriology 100, 23I-239.

ZIPSER, D. (1969). Polar mutations and operon function. Nature, London 22I, 2 I-25. 